\section{Methylazo and Methylazoxy Gompounds; New Types of Antitumour Agents}

Recently we described the antitumour activity of methylhydrazine derivatives ${ }^{1-3}$. A series of oxidation products of the methylhydrazine derivatives, azo and azoxy compounds, have been synthesized and tested for tumour inhibiting activity.

(1) Chemistry. The azo compounds were prepared from the corresponding methylhydrazine derivatives by oxidation with mercuric oxide or with oxygen in an inert solvent. $N$-isopropyl- $\alpha$-[methylazo]- $p$-toluamide (I) has the m.p. $111-115^{\circ}$ (dec.) and is further characterized by an ultraviolet absorption, maximum at $233 \mathrm{~m} \mu\left(\mathrm{E}_{1 \% \mathrm{~m}}^{1 \%}\right.$ $=635$ ) in ethanol. Oxidation of this substance with one mole of perbenzoic acid in methylene chloride yielded $\mathbb{N}$ isopropyl- $\alpha$-[methylazoxy]-p-toluamide (II), m.p. 128$132^{\circ}$ (dec.), absorbing in the infrared at 6.58 and $7.56 \mu$. This product possibly represents a mixture of isomeric azoxy compounds.

(2) Tumour experiments. Methods: The experiments were carried out on the following transplantable tumours: Ehrlich carcinoma (solid form), Ehrlich carcinoma (ascitic form), and Walker carcinosarcoma 256. In the case of tumours growing in solid form, small tumour fragments were implanted subcutaneously, whereas for the Ehrlich ascites carcinoma, ascites cells were injected intraperitoneally. Groups of ten animals were used for each dose. Daily administration of the compounds, either in aqueous solution or in suspensions in propylene glycol, was started on the day after implantation by the intraperitoneal route. Five to seven daily doses were given, varying according to the kind of tumour. The day after the last dose had been given, the tumours were excised and weighed. In the case of the ascites carcinoma the survival time was determined.

Results: Generally, in all three tumour systems there was a certain parallelism in the antitumour activity between the methylazo or the methylazoxy derivatives and their corresponding methylhydrazine analogues. However, the azo and azoxy compounds usually showed a lower grade of tumour inhibiting activity than their hydrazine analogues. As an example, the effect of $I$ and II on the Walker tumour of the rat is compared with the activity of the corresponding $N$-isopropyl- $\alpha$-[methylhydrazino]-ptoluamide hydrochloride (III). In the Table, the following mean data are indicated: tumour weight, change in weight of the animals, tumour weight index controls/treated (C/T) $\%$ of tumour inhibition and therapeutic index. In the Walker tumour experiments the therapeutic index is the ratio between the maximum tolerated dose (MTD) (daily dose in a 10-day subacute toxicity test in which no loss in weight and no leukopenia occur), and the minimum $100 \%$ effective dose (MED 100\%) (lowest daily dose which leads to complete inhibition of the growth of the Walker tumour).

From the Table it can be seen that both I and II are able to inhibit completely the growth of the Walker carcinosarcoma. The therapeutic index of both compounds, however, is lower than that of the corresponding methylhydrazine derivative III.

Little is known about the mechanism by which these compounds act. In vitro experiments present some difficulty because of the insolubility of these substances in water. It was found previously that autoxidation of the methylhydrazine derivatives to the corresponding azo compounds produces hydrogen peroxide ${ }^{4}$ which may be responsible for the DNA-fragmentation and perhaps for the antitumour effect in vivo. Physicochemical investigations have shown that methylhydrazine derivatives degrade deoxyribonucleic acid in the presence of oxygen. Whether the above mentioned azo and azoxy compounds are reduced in vivo to the corresponding hydrazine is not known. Experiments in this direction are in progress.

Zusammenfassung. Die tumorhemmende Wirkung von Methylazo- und Methylazoxyverbindungen wird beschrieben. Der cytostatische Effekt dieser Substanzen geht meistens demjenigen der analogen Methylhydrazinderivate parallel. Die Aktivität ist geringer und die therapeutischen Indices der Azo- und Azoxyverbindungen sind ungünstiger als diejenigen der entsprechenden Methylhydrazinverbindungen.

W. BOLlag, A. KaISER,

A. LANGEMANN, and P. ZELLLER

Forschungsabteilung der F. Hoffmann-La Roche \& Co. AG., Basel (Stritzerland), June 3, 1964.

1 P. Zeller, H. Gutmane, B. Hegedú, A. Katser, A. Langemann, and M. MOLLER, Exper. 19, 129 (1963).

2 W. Bollag and E. Gruniberg, Exper. 19, 130 (1963).

$s$ W. Bollag, Cancer Chemother. Rep. No. 33, p. 1 (1963).

4 K. Berneis, M, Kofler, W. BollaG, A. Katser, and A. LANGeMANN, LXper. 19, 132 (1963).

Effect on the Walker carcinosarcoma (intraperitoneal administration, six times within eight days)

\begin{tabular}{|c|c|c|c|c|c|c|}
\hline & $\begin{array}{l}\text { Daily dose } \\
(\mathrm{mg} / \mathrm{kg})\end{array}$ & $\begin{array}{l}\text { Tumor weight } \\
\text { (mg) }\end{array}$ & $\begin{array}{l}\text { Weight change } \\
\text { of rats }\end{array}$ & $\begin{array}{l}\text { Tumor weight } \\
\text { index } c / T\end{array}$ & $\begin{array}{l}\text { Tumor inhibition } \\
(\%)\end{array}$ & $\begin{array}{l}\text { Therapeutic index } \\
\text { MTD }\end{array}$ \\
\hline & & & & & & MED $100 \%$ \\
\hline $\begin{array}{l}\text { Methylhydrazine } \\
\text { compound III }\end{array}$ & $\begin{array}{l}\text { Controls } \\
5 \\
10\end{array}$ & $\begin{array}{l}14.825 \\
2.760 \\
0\end{array}$ & $\begin{array}{l}+34.7 \\
+29.9 \\
+19.8\end{array}$ & $\begin{array}{l}1 \\
5.3 \\
\infty\end{array}$ & $\begin{array}{c}0 \\
81.3 \\
100\end{array}$ & $\frac{75 \mathrm{mg} / \mathrm{kg}}{10 \mathrm{mg} / \mathrm{kg}}=7.5$ \\
\hline $\begin{array}{l}\text { Methylazo } \\
\text { compound I }\end{array}$ & $\begin{array}{l}\text { Controls } \\
5 \\
10\end{array}$ & $\begin{array}{l}14.277 \\
2.021 \\
0\end{array}$ & $\begin{array}{l}+25.8 \\
+17.7 \\
+12.2\end{array}$ & $\begin{array}{l}1 \\
7.1 \\
\infty\end{array}$ & $\begin{array}{c}0 \\
85.9 \\
100\end{array}$ & $\frac{30 \mathrm{mg} / \mathrm{kg}}{10 \mathrm{mg} / \mathrm{kg}}=3.0$ \\
\hline $\begin{array}{l}\text { Methylazoxy } \\
\text { compound II }\end{array}$ & $\begin{array}{l}\text { Controls } \\
5 \\
10 \\
20\end{array}$ & $\begin{array}{c}16.520 \\
11.794 \\
4.651 \\
0\end{array}$ & $\begin{array}{r}+41.4 \\
+40.3 \\
+24.6 \\
+18.0\end{array}$ & $\begin{array}{l}1 \\
1.4 \\
3.6 \\
\infty\end{array}$ & $\begin{array}{c}0 \\
28.6 \\
71.8 \\
100\end{array}$ & $\frac{70 \mathrm{mg} / \mathrm{kg}}{20 \mathrm{mg} / \mathrm{kg}}=3.5$ \\
\hline
\end{tabular}

\footnotetext{
Values are the mean for ten animals per dose level.
} 